\title{
Bee Flora and Use of Resources by Africanized Bees
}

\author{
Joseane Inácio da Silva Moraes ${ }^{1}$ (1) 0000-0001-5660-3124 \\ Maria Teresa do Rêgo Lopes ${ }^{2}$ (1) 0000-0002-8814-1072 \\ Regina Lucia Ferreira-Gomes ${ }^{1}$ (1) 0000-0002-7700-6959 \\ Angela Celis de Almeida Lopes ${ }^{1}$ (1) 0000-0002-9546-5403 \\ Fábia de Mello Pereira ${ }^{2}$ (1) 0000-0001-6696-1726 \\ Bruno de Almeida Souza ${ }^{2}$ (1) 0000-0003-3692-3993 \\ Leudimar Aires Pereira ${ }^{1}$ (1) 0000-0002-8594-1613
}

\begin{abstract}
Beekeeping is affected by adverse climatic conditions and availability of floral resources. This study aimed to survey and characterize the flora in São João do Piauí, a semi-arid region in Piauí, Brazil, and to identify species providing resources to bees. Flowering plants were observed for 18 months, and records were taken of flowering date, growth habit, visitation and resources collected by bees. Melissopalinological analysis of honey produced in the area was performed. A total of 67 flowering plant species were recorded, of which 49 were considered as bee plants, with a predominance of herbs and shrubs. The low rainfall reduces the number of flowering species, which makes important the conservation and multiplication of species which bloom in dry season, such as Ipomoea glabra, Myracrodruon urundeuva, Sida cordifolia and Ziziphus joazeiro, as well as species that contribute to honey production such as Mimosa tenuiflora, Mesosphaerum suaveolens and Croton sonderianus.
\end{abstract}

Keywords: nectar, pollen, floral resources.

\section{INTRODUCTION AND OBJECTIVES}

The Northeast region of Brazil has been highlighted for its great potential in beekeeping activity, with the state of Piauí as one of the largest honey producers in the country (IBGE, 2018). However, beekeeping, as well as other agricultural activities, can suffer significant losses due to the climatic conditions of the region, especially the large spatial and temporal variability of rainfall (Marengo, 2008; Silva et al., 2011).

Although flowering occurs abundantly during the rainy season in caatinga regions, flowering species significantly reduce in number in the dry season, thus reducing the natural supply of available food to bees (Rodarte et al., 2008; Silva et al., 2008; Silva Filho et al., 2010). This situation worsens when the drought season is prolonged in the region in years considered very dry, as that which occurred in 2012 when the amount of rainfall was irregular, poorly distributed and below the historical average of the Northeast (Santos et al., 2012).
As a result, several beekeepers lost their colonies, which migrated in search of food sources in other areas. The decrease of honey production in states such as Pernambuco and Piauí reached $70 \%$ compared to the previous year (Vidal, 2014).

Beekeepers need to provide supplementary food, water of good quality and adequate shading to the colonies to avoid or minimize losses during the drought period (Pereira et al., 2011; Pereira et al., 2014). Part of these needs can be met by plant species that bloom in dry season and provide a good level of shading; thus, preserving and planting these species in areas explored by bees is recommended (Lopes et al., 2011; Santos et al., 2017). In this context, studies of local bee flora diversity are important because they make it possible to identify the species that constitute the region's beekeeping pasture and to recognize those that contribute to the food supply for bees during the off-season.

Thus, this study aimed to: a) identify the flora exploited by bees in the municipality of São João do Piauí, in the semi-arid

\footnotetext{
${ }^{1}$ Universidade Federal do Piauí (UFPI), Teresina, PI, Brasil

${ }^{2}$ Embrapa Meio-Norte, Teresina, PI, Brasil
} 
region of Piauí state; b) characterize the species regarding their growth habit, the resources offered to the bees, and the flowering period; and c) identify the species that contribute to producing honey in the region and to maintaining the swarms during dry seasons.

\section{MATERIALS AND METHODS}

\subsection{Study area}

The study was conducted at Monte Orebe Experimental Farm, located in São João do Piauí (08 $21^{\circ} 29^{\prime \prime} \mathrm{S}$ and $\left.42^{\circ} 14^{\prime} 48^{\prime \prime} \mathrm{W}\right)$ in Southern Piauí, approximately $460 \mathrm{~km}$ from the capital city of Teresina. Semi-arid is the predominant climate of the region, with caatinga shrub vegetation and trees with varying densities. The semi-arid climate is characterized by the presence of high temperatures and irregular rainfall, with average annual temperatures between $26^{\circ} \mathrm{C}$ and $28^{\circ} \mathrm{C}$, predominating long dry periods (Andrade Jr et al., 2004). According to INMET ([2015?]), the average total rainfall in the municipality from 2004 to 2013 was $625 \mathrm{~mm}$, with the highest concentration in four months (Figure 1).

An average temperature of $28.8^{\circ} \mathrm{C}$, with a minimum of $22.9^{\circ} \mathrm{C}$ and a maximum of $35.7^{\circ} \mathrm{C}$, an average air humidity of $51.5 \%$ with a minimum of $24.8 \%$ and a maximum of $53.3 \%$ were recorded during the study period by a meteorological station installed on the experimental farm. The cumulative rainfall was $254 \mathrm{~mm}$ and $702 \mathrm{~mm}$ in 2012 and 2013, respectively.

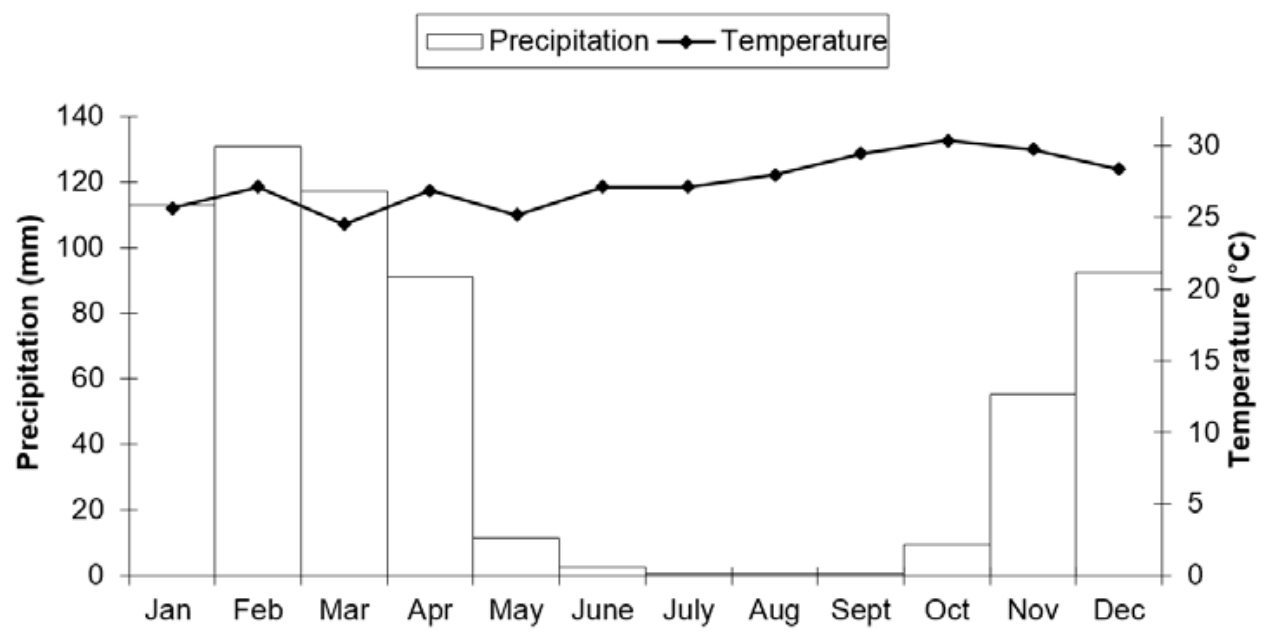

Figure 1. Precipitation and temperature data for São João do Piauí, PI, Brazil, ten-year period average (2004-2013).

Source: INMET, 2015.

\subsection{Survey of beekeeping flora}

Direct collections and observations of flowering plant species were performed in the area for 18 months (April 2012 to September 2013). Collections were performed monthly from April 2012 to January 2013, as little material was available to collect in the very dry vegetation. Biweekly collections were performed when there was a higher volume of precipitation in the subsequent period and consequently a greater number of flowering plants (February to September 2013). The trail on which the botanical species were collected was approximately $2,500 \mathrm{~m}$ long and $5 \mathrm{~m}$ wide and surrounded the experimental apiary. The trail was coursed in the morning and afternoon the same day or in two days to observe the times when resources were offered to bees by plant species.
All species that presented reproductive material were collected by the Preferred Collection Method (PCM), according to Castro (1994), considering a number of five samples per species. We observed and took notes on the species that were in bloom, the ones that were visited by bees, and the bees' behavior in the collection of floristic resources.

The collected plant species were characterized as to the growth forms in herbaceous, shrub, sub-shrub, liana and tree.

Identification of botanical species was performed by comparing with similar and previously identified materials, and by consulting the appropriate literature and experts. The identified materials were deposited at the Embrapa Mid-North Herbarium. The botanical classification system from the Angiosperm Philogeny Group (APG III, 2009) was adopted. 


\subsection{Preparation of the pollen slides}

The collected flower samples were stored in 70\% alcohol Eppendorf tubes and then placed in a refrigerator. Pollen grains were removed from the inflorescences in the laboratory to prepare slides, following the methodology proposed by Barth (1970a; 1970b; 1970c; 1970d), with some adaptations.

\subsection{Melissopalinological analysis}

In order to compare the pollen present in honey with the pollen of the inventoried botanical species, a sample of $50 \mathrm{~mL}$ centrifuged honey produced in beehives of the evaluated area was collected in May 2013, period in which honey is harvested at the experimental farm.

The slides were prepared following the methodology proposed by Barth (1989). The pollen types were qualitatively analyzed by comparing the pollen slides of the botanical species collected in the studied area and with the help of specialized literature. Quantitative analysis was performed by counting 300 pollen grains per sample, determining the occurrence classes, which according to Louveaux et al. (1978) are: dominant pollen (DP, $>45 \%$ of total grains), accessory pollen (AP, $16 \%$ to $45 \%$ ), important isolated pollen (IIP, 3\% to 15\%) and occasional isolated pollen (OIP, <3\%).

\section{RESULTS AND DISCUSSION}

A total of 67 flowering species were identified, of which 49 provide some type of resource (nectar, pollen or resin) for bees (Table 1). Fabaceae, Malvaceae, and Euphorbiaceae botanical families presented the largest number of representatives visited by the bees. These families also stood out with a significant number of melitophilous species in other surveys conducted in the Northeast (Chaves et al., 2007; Lopes et al., 2016; Lorenzon et al., 2003; Rodarte et al., 2008; Santos et al., 2006; Silva et al., 2014a). The area was predominantly herbaceous (26), followed by shrubs (13), lianas (11), subshrubs (10) and tree species (7) (Table 1).

The herbaceous and shrub species bloom most intensely in the rainy and early dry seasons, respectively (Figure 2). Herbaceous plants as apicultural plants are important in the rainy months mainly due to the considerable number of species that provide pollen and nectar during this period and to the presence of flowers closer to the hives (Rodarte et al., 2008). However, the contribution of the herbaceous stratum in the bee pasture is often restricted to the rainy season in regions of high seasonality such as caatinga (Araújo et al., 2005, Reis et al.; 2006). A greater number of flowering herbaceous species were observed in the months of March and April 2013 (the end of the rainy season) in this study.

Table 1. Growth form, blooming period, visitation and resources collected by bees of flowering species in São João do Piauí, Piauí, Brazil, from April 2012 to September 2013.

\begin{tabular}{|c|c|c|c|c|}
\hline Family/Species & $\begin{array}{l}\text { Growth } \\
\text { form }\end{array}$ & Flowering season & $\begin{array}{l}\text { Visitation } \\
\text { by bees }\end{array}$ & $\begin{array}{l}\text { Collected } \\
\text { resource* }\end{array}$ \\
\hline \multicolumn{5}{|l|}{ Amaranthaceae } \\
\hline Alternanthera philoxeroides (Mart.) Griseb. & Herb & Apr, May & $\mathrm{Y}$ & $\mathrm{N}^{1}$ \\
\hline Alternanthera tenella Colla & Herb & Feb, May & - & $\mathrm{N}^{2}$ \\
\hline \multicolumn{5}{|l|}{ Anacardiaceae } \\
\hline Myracrodruon urundeuva Allemão & Tree & May, June, July & Y & $\mathrm{P} / \mathrm{N}^{1,2,4,5,6,7}$ \\
\hline Spondias tuberosa Arruda & Tree & Jan & - & $\mathrm{N}^{2,6}$ \\
\hline \multicolumn{5}{|l|}{ Apocynaceae } \\
\hline Calotropis procera (Aiton) W. T. Aiton & Shr & $\begin{array}{c}\text { Jan, Feb, Mar, Apr, June, July, Aug, Sept, } \\
\text { Oct, Nov }\end{array}$ & Y & $\mathrm{P} / \mathrm{N}^{1}$ \\
\hline \multicolumn{5}{|l|}{ Bignoniaceae } \\
\hline Clytostoma campanulatum Bureau \& K. Schum. & Lia & Apr & - & $\mathrm{N}^{8}$ \\
\hline Cuspidaria sp. & Shr & Dec & - & $\mathrm{N}^{8}$ \\
\hline Fridericia dichotoma (Jacq.) L.G. Lohmann & Lia & Apr, May, June & - & $\mathrm{P} / \mathrm{N}^{3}$ \\
\hline $\begin{array}{l}\text { Neojobertia candolleana (Mart. ex DC.) Bureau \& } \\
\text { K. Schum. }\end{array}$ & Lia & Apr & - & $\mathrm{N}^{5}$ \\
\hline \multicolumn{5}{|l|}{ Bombacaceae } \\
\hline Pachira aquatica Aubl. & Tree & June, July & - & \\
\hline \multicolumn{5}{|l|}{ Boraginaceae } \\
\hline Heliotropium indicum L. & Herb & May, June, July, Aug, Sept, Oct & - & $* * 11$ \\
\hline Euploca procumbens (Mill) Diane \& Hilger & Herb & Mar & - & \\
\hline \multicolumn{5}{|l|}{ Burseraceae } \\
\hline Commiphora leptophloeos (Mart.) J. B. Gillett & Tree & Jan & - & $\mathrm{P} / \mathrm{N}^{2,6,7}$ \\
\hline Combretaceae & & & - & \\
\hline Combretum leprosum Mart. & Shr & Mar, Apr & $\mathrm{Y}$ & $\mathrm{P} / \mathrm{N}^{1,2,3,6,7}$ \\
\hline
\end{tabular}


Table 1. Continued...

\begin{tabular}{|c|c|c|c|c|}
\hline Family/Species & $\begin{array}{l}\text { Growth } \\
\text { form }\end{array}$ & Flowering season & $\begin{array}{l}\text { Visitation } \\
\text { by bees }\end{array}$ & $\begin{array}{l}\text { Collected } \\
\text { resource }\end{array}$ \\
\hline \multicolumn{5}{|l|}{ Commelinaceae } \\
\hline Commelina obliqua Vahl. & Herb & Apr & - & \\
\hline Convolvulaceae & & & - & \\
\hline Evolvulus brevifolius (Meisn.) Ooststr. & Lia & Dec & - & \\
\hline Evolvulus sp. & Lia & Mar, Apr & - & \\
\hline Ipomoea asarifolia (Desr.) Roem. \& Schult. & Lia & Apr, May, June, July, Aug, Sept & - & $\mathrm{P}^{3,7}$ \\
\hline Ipomoea bahiensis Willd. Ex. Roem. \& Schult. & Lia & Apr & - & $\mathrm{N}^{4,5,7}$ \\
\hline Ipomoea glabra (Aubl.) Choisy & Lia & May, June, July, Aug, Sept & $\mathrm{Y}$ & $\mathrm{N}^{1}$ \\
\hline Ipomoea wrightii A. Gray & Lia & Feb & - & \\
\hline Jacquemontia sphaerostigma (Cav.) Rusby. & Herb & Mar & - & \\
\hline \multicolumn{5}{|l|}{ Euphorbiaceae } \\
\hline Croton betaceus Baill. & Sub & Feb, Apr & $\mathrm{Y}$ & $\mathrm{N}^{1}$ \\
\hline Croton campestris A. St.-Hil. & Shr & Jan, Feb, Mar & - & $\mathrm{N}^{7}$ \\
\hline Croton mucronifolius Müll. Arg. & Shr & Mar & $\mathrm{Y}$ & $\mathrm{N}^{1}$ \\
\hline Croton sonderianus Müll. Arg. & Shr & Jan, Mar & $\mathrm{Y}$ & $\mathrm{P} / \mathrm{N}^{1,2,4,5,6,7}$ \\
\hline Croton zehntneri Pax e K. Hoffm. & Sub & Dec & - & $\mathrm{N}^{10}$ \\
\hline Jatropha pohliana Müll. Arg. & Shr & Feb & - & $\mathrm{N}^{7}$ \\
\hline Manihot sp. & Sub & Jan & - & \\
\hline \multicolumn{5}{|l|}{ Fabaceae/Caesalpinioideae } \\
\hline Bauhinia forficata Link & Shr & Apr & - & $* * 11$ \\
\hline Caesalpinia microphylla Mart. ex G. Don & Shr & Jan, Feb & - & $\mathrm{N}^{4}$ \\
\hline $\begin{array}{l}\text { Chamaecrista supplex (Mart. Ex Benth.) Britton } \\
\text { \& Rose ex Britton \& Killip. }\end{array}$ & Herb & Mar, Apr & - & $\mathrm{P}^{2}$ \\
\hline Senna lechriosperma H. S. Irwin \& Barneby & Sub & Apr & - & $\star * 12$ \\
\hline Senna obtusifolia (L.) S. Irwin \& Barneby & Sub & Feb, Apr, May & - & $\mathrm{P}^{2,7}$ \\
\hline Poincianella pyramidalis (Tul.) L. P. Queiroz & Tree & Feb, Apr & $\mathrm{Y}$ & $\mathrm{P}^{1}$ \\
\hline \multicolumn{5}{|l|}{ Fabaceae/Faboideae } \\
\hline Macroptilium lathyroides (L.) Urb. & Herb & Feb, Apr, May & - & \\
\hline Stylosanthes guianensis (Aubl.) Sw. & Herb & Apr & - & $\mathrm{P} / \mathrm{N}^{9}$ \\
\hline \multicolumn{5}{|l|}{ Fabaceae/Mimosoideae } \\
\hline Mimosa arenosa (Willd.) Poir. & Shr & Abr & $\mathrm{Y}$ & $\mathrm{P} / \mathrm{N}^{1,2}$ \\
\hline Mimosa quadrivalvis $\mathrm{L}$. & Herb & Mar, Apr & - & $\mathrm{P} / \mathrm{N}^{2}$ \\
\hline Mimosa sp. & Shr & Apr & - & \\
\hline Neptunia oleracea Lour. & Sub & Feb, Apr & - & \\
\hline Mimosa tenuiflora (Willd.) Poir. & Tree & Mar, Apr, July, Aug, Nov & $\mathrm{Y}$ & $\mathrm{P} / \mathrm{N}^{1,2,3,6}$ \\
\hline Schrankia leptocarpa DC. & Herb & Jan & $\mathrm{Y}$ & $\mathrm{N}^{1,7}$ \\
\hline \multicolumn{5}{|l|}{ Hydroleaceae } \\
\hline Hydrolea spinosa L. & Herb & Aug & - & \\
\hline \multicolumn{5}{|l|}{ Lamiaceae } \\
\hline Mesosphaerum suaveolens (L.) Kuntze & Herb & Apr & $\mathrm{Y}$ & $\mathrm{N}^{1,2,6}$ \\
\hline \multicolumn{5}{|l|}{ Malpighiaceae } \\
\hline Banisteriopsis sp. & Shr & Aug, Sept & - & \\
\hline Banisteriopsis stellaris (Griseb.) B. Gates. & Shr & Apr, July & - & $\mathrm{P} / \mathrm{N}^{9}$ \\
\hline Stigmaphyllon sp. & Lia & May & - & \\
\hline Stigmaphyllon tomentosum A. Juss. & Lia & Apr & - & \\
\hline \multicolumn{5}{|l|}{ Malvaceae } \\
\hline Herissantia crispa (L.) Brizicky & Sub & Apr & $\mathrm{Y}$ & $\mathrm{N}^{1,7}$ \\
\hline Herissantia tiubae (K. Schum.) Brizicky & Sub & May, June, July & $\mathrm{Y}$ & $\mathrm{P} / \mathrm{N}^{1,2}$ \\
\hline Pavonia cancellata (L.) Cav. & Herb & May, July & - & $\mathrm{P} / \mathrm{N}^{2,3,7}$ \\
\hline Sida cordifolia L. & Herb & Apr, May, June, July & $\mathrm{Y}$ & $\mathrm{P} / \mathrm{N}^{1,2,7}$ \\
\hline Sida rhombifolia L. & Herb & Mar, Apr, Sept, Oct, Nov & $\mathrm{Y}$ & $\mathrm{N}^{1,3}$ \\
\hline Sida urens L. & Herb & Feb & - & $* * 11$ \\
\hline Waltheria indica L. & Sub & May, Jul, Aug, Sept & - & $\mathrm{P} / \mathrm{N}^{3,4,9}$ \\
\hline
\end{tabular}


Table 1. Continued...

\begin{tabular}{|c|c|c|c|c|}
\hline Family/Species & $\begin{array}{l}\text { Growth } \\
\text { form }\end{array}$ & Flowering season & $\begin{array}{l}\text { Visitation } \\
\text { by bees }\end{array}$ & $\begin{array}{l}\text { Collected } \\
\text { resource }\end{array}$ \\
\hline \multicolumn{5}{|l|}{ Nyctaginaceae } \\
\hline Boerhavia coccinea Mill. & Herb & Apr & $\mathrm{Y}$ & $\mathrm{P} / \mathrm{N}^{1,5,7}$ \\
\hline \multicolumn{5}{|l|}{ Oxalidaceae } \\
\hline Oxalis corniculata $\mathrm{L}$. & Herb & Apr, May & $\mathrm{Y}$ & $\mathrm{N}^{1}$ \\
\hline Oxalis divaricata Mart. ex Zucc. & Herb & Mar & - & $\mathrm{N}^{2}$ \\
\hline \multicolumn{5}{|l|}{ Passifloraceae/Turneroideae } \\
\hline Piriqueta rosea (Cambess.) Urb. & Herb & Mar & - & \\
\hline Turnera pumilea L. & Herb & Mar, Apr & $\mathrm{Y}$ & $\mathrm{P}^{1}$ \\
\hline Turnera ulmifolia L. & Herb & Jan, Feb, Mar, Apr, May, July, Aug, Sept & $\mathrm{Y}$ & $\mathrm{N}^{1,4,7}$ \\
\hline \multicolumn{5}{|l|}{ Polygalaceae } \\
\hline Polygala paniculata L. & Herb & Apr & - & \\
\hline \multicolumn{5}{|l|}{ Rhamnaceae } \\
\hline Ziziphus joazeiro Mart. & Tree & Aug, Sept & $\mathrm{Y}$ & $\mathrm{P} / \mathrm{N} / \mathrm{R}^{1,2,4,5,6,7}$ \\
\hline \multicolumn{5}{|l|}{ Rubiaceae } \\
\hline Borreria verticillata (L.) G. Mey. & Herb & Apr, May & - & $\mathrm{N}^{2,4,5,6,7}$ \\
\hline Diodella teres (Walter) Small & Sub & Mar & - & $\mathrm{P} / \mathrm{N}^{2,3,4}$ \\
\hline Staelia sp. & Herb & Apr & & \\
\hline
\end{tabular}

Herb: Herbaceous; Tree: Trees; Shr: Shrubs; Sub: Subshrubs; Lia: Lianas; Y: Yes; -: No; N: Nectar; P: Pollen; R: Resin.

* When bee visitation and resource collection were not observed in this study, the information was obtained in the literature.

${ }^{*}$ Bee visitation reported in the literature, but with no information on collected resources.

${ }^{1}$ Observation of this study; ${ }^{2}$ Maia-Silva et al. (2012); ${ }^{3}$ Lopes et al. (2016); ${ }^{4}$ Santos et al. (2006); ${ }^{5}$ Silva et al. (2014b); ${ }^{6}$ Santos et al. (2005); ${ }^{7}$ Silva et al. (2014a); ${ }^{8}$ Scudeller et al. (2008); ${ }^{9}$ Andena et al. (2005); ${ }^{10}$ Silva et al. (2009); ${ }^{11}$ Almeida et al. (2003); ${ }^{12}$ Milet-Pinheiro \& Schlindwein (2008).

\begin{tabular}{|ll|}
\hline DDy season $\quad$ QRainy season \\
\hline
\end{tabular}

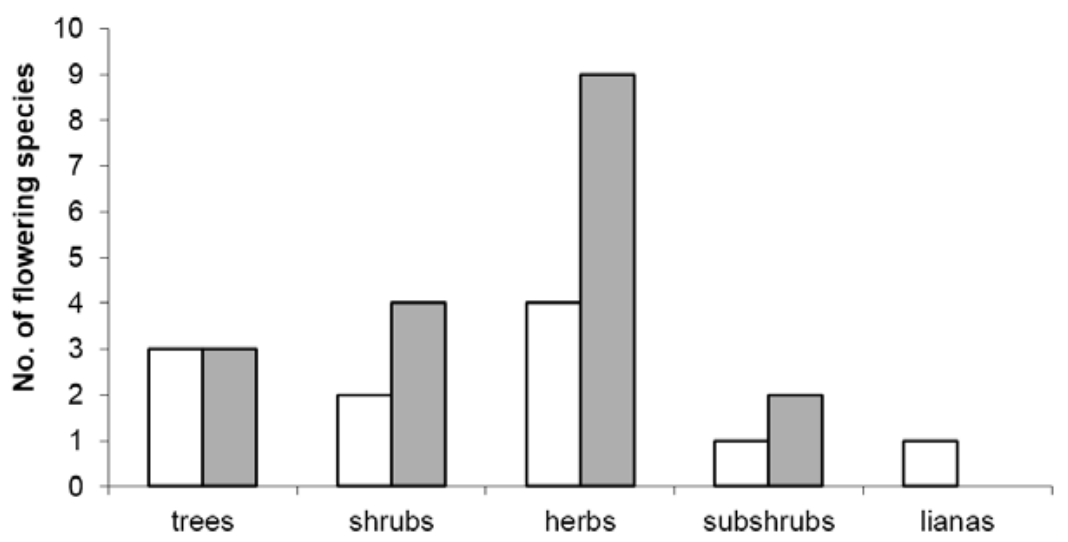

Figure 2. Distribution of plant species collected in São João do Piauí, Piauí, Brazil, in relation to growth form in dry and rainy seasons from April 2012 to September 2013.

This study found that the rainfall regime had great influence on the flora of the region, with the increase in precipitation significantly increasing the number of flowering species (Figure 3). The maximum number of flowering species occurred in April 2013, at the end of the rainy season. Noteworthily, the accumulated rainfall from January to April in this year was $431 \mathrm{~mm}$, almost three times higher than in the same period of $2012(159 \mathrm{~mm})$. The months with the lowest offer of floral resources were October and November.

A reduction in food supply to bees caused by climate factors contributes to a decrease in beekeeping production, which has been especially observed in periods of severe drought in the Northeast (Alcoforado Filho \& Gonçalves, 2000; Vidal, 2014). 


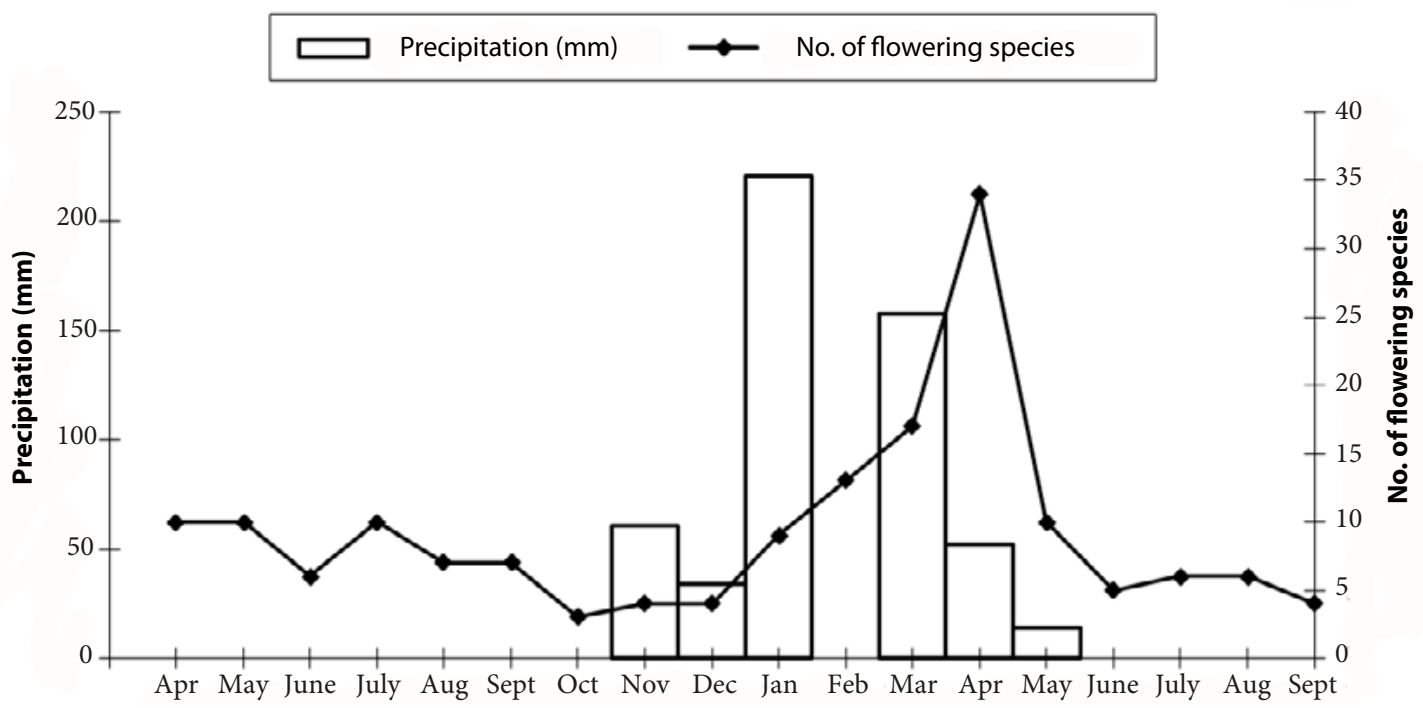

Figure 3. Precipitation and number of plant species in bloom in São João do Piauí, Piauí, Brazil, from April 2012 to September 2013.

In addition to the low rainfall, the high temperatures recorded in the period (average maximum of $35.7^{\circ} \mathrm{C}$ ) and the low relative humidity (average minimum of $24.8 \%$ ) may have been limiting factors to bee visitations. This may justify why some species recognized as apicultural plants were not visited by bees in this study (Table 1). According to Crane (1983), climatic factors interfere with nectar secretion, which may influence the collection of this resource by bees. In this context, Malerbo-Souza \& Silva (2011) found that relative humidity values below $40 \%$ are limiting for nectar collection by Apis mellifera.

Regarding the type of resource offered to bees, it became evident that $73 \%$ of the sampled species offer some type of food resource (Table 1). According to observed and literature data, 22 species provide nectar, 5 provide pollen, and 17 provide both resources. Resin supply was only observed in Ziziphus joazeiro Mart.

Santos et al. (2006) found that $72.5 \%$ of the species observed in the caatinga region of Pernambuco only offered nectar, while in a survey conducted in a cerrado area in Piauí, Lopes et al. (2016) found that $88.6 \%$ of the sampled species offered both pollen and nectar to bees. These results demonstrate the great variability in the resources available for bees in different locations, which reinforces the importance of studies on flora to evaluate the region's apicultural potential.

Among the species that flowered in the rainy season, Combretum leprosum, Croton sonderianus, Turnera ulmifolia, Mimosa tenuiflora, Mimosa arenosa, Ipomoea glabra, Mesosphaerum suaveolens and Sida cordifolia are recognized as nectar and pollen sources and are important to produce honey in caatinga regions (Maia-Silva et al., 2012; Santos et al., 2005; Santos et al., 2006).

In the dry season, the species Myracrodruon urundeuva, Z. joazeiro, I. glabra, M. tenuiflora and T. ulmifolia stand out (Table 1), which are important to maintain the colonies, as their flowering occurs in a period considered critical for bees in the semi-arid region (Alcoforado Filho \& Gonçalves, 2000; Pereira et al., 2006). Commiphora leptophloeos stands out for its importance for native nesting bee species (Martins et al., 2004). Thus, it is important for the beekeeper to preserve, conserve and promote species multiplication, which contribute to maintain colonies during drought, reducing spending on the use of artificial feeding at times when the supply of floral resources to bees is sharply declining.

Although known for flowering in the dry season, $M$. tenuiflora flowered at different times of the year in this study, providing floral resources to bees in both dry and rainy seasons. This species is characterized by fast growth and by providing large quantities of pollen to the bees (Maia-Silva et al., 2012).

The occurrence of plants with different flowering periods in the area explored by bees is important because it enables food supply at different times of the year. $Z$. joazeiro, $M$. urundeuva and $M$. tenuiflora are among the species with the highest flowering period.

The presence of bees was observed in some botanical species during the 18 months of study, except for December when the species that were in flowering received no visitation. In a similar study, Lorenzon et al. (2003) did not observe bee visitation to plant species in the months of August and October. 
The qualitative melissopalinological analysis of honey collected in the apiary of the studied area showed the diversity of nectar sources visited by A. melifera in its foraging activity. Eight pollen types were identified and distributed in six families (Table 2). Five types belong to species in which bee visits were observed, while the others belong to botanical species considered melitophilous by other authors (Table 1). The family with the greatest diversity of pollen types was Fabaceae, which also stands out as an important source of bee resources in other studies conducted in the Northeast (Rolim, 2015; Santos et al. 2006; Sodré et al.; 2008; Trovão et al., 2009;). The bees mainly collected resources in the herbaceous $(62.5 \%)$ stratum, followed by shrub $(25 \%)$ and tree (12.5\%) stratums. These results highlight the importance of herbaceous sources as suppliers of food resources for bees in the Northeast, especially in the caatinga region (Lopes et al., 2016; Lorenzon et al., 2003; Santos et al., 2006).

The presence of $C$. sonderianus pollen was not identified, a species collected in this study (Table 1) and recognized as potential for bees, mainly as a nectar supplier (MaiaSilva et al., 2012; Pereira et al., 2006; Silva et al., 2008). This absence is probably due to the discontinuity in rainfall in February 2013 (Figure 3), exactly in the flowering period of this species, which may have affected flowering and the consequent supply of nectar. The presence of pollen types from species that flower in the dry season, M. tenuiflora and S. rhombifolia, confirm the importance of these species to maintain colonies in drought periods.

Dominant pollen was absent in the quantitative pollen analysis (Table 2). We highlight the participation of $M$. tenuiflora, M. arenosa (Fabaceae) and M. suaveolens (Lamiaceae) species in honey production. These species are important sources of pollen and nectar for bees (Maia-Silva et al., 2012; Pereira et al., 2006). The melissopalinological analysis confirms the importance of the Fabaceae family as a source of food resources for A. mellifera and indicates that the region's flora provides a diversified bee pasture and a heterofloral honey.

Table 2. Pollen spectrum of Apis mellifera honey samples collected in São João do Piauí, Piauí, in 2013. Occurrence classes: DP: dominant pollen (>45\%); AP: accessory pollen (16\%-45\%); IIP: important isolated pollen (3\%-15\%) and OIP: occasional isolated pollen.

\begin{tabular}{|c|c|c|c|c|c|}
\hline \multirow{2}{*}{ Family } & \multirow{2}{*}{ Pollen Types } & \multicolumn{4}{|c|}{ Occurrence (\%) } \\
\hline & & $\overline{D P}$ & $\mathbf{A P}$ & IIP & OIP \\
\hline Amaranthaceae & Alternanthera tenella & & & 9.0 & \\
\hline Combretaceae & Combretum leprosum & & & 6.0 & \\
\hline \multirow{3}{*}{ Fabaceae } & Macroptilium lathyroides & & & 4.0 & \\
\hline & Mimosa arenosa & & & 11.0 & \\
\hline & Mimosa tenuiflora & & 42.0 & & \\
\hline Lamiaceae & Mesosphaerum suaveolens & & 21.0 & & \\
\hline Malvaceae & Sida rhombifolia & & & & 1.0 \\
\hline Rubiaceae & Borreria verticillata & & & 6.0 & \\
\hline
\end{tabular}

\section{CONCLUSIONS}

The municipality of São João do Piauí, located in the Piauí semi-arid region, has diverse flora with a significant number of bee nectar and pollen suppliers, especially the Fabaceae, Malvaceae and Euphorbiaceae families.

Herbaceous and shrub species predominate among the plants visited by the bees, which bloom mainly during the rainy season. These strata are greatly affected by climatic conditions, with a significant reduction in the number of flowering species in periods of low rainfall.

The period with the highest number of species in flowering is from February to April, with an emphasis on the Combretum leprosum, Croton sonderianus, Turnera ulmifolia, Mimosa tenuiflora, Mimosa arenosa, Ipomoea glabra, Mesosphaerum suaveolens and Sida cordifolia species, which provide pollen and nectar to the bees. Ipomoea glabra, Myracrodruon urundeuva, Sida cordifolia and Ziziphus joazeiro species are among those which flower in the dry season with pollen and nectar supply, therefore being important to maintain colonies during this period.

The honey produced in the region has varied botanical sources, important participation by herbaceous species and a significant contribution from the Fabaceae family in the composition.

\section{ACKNOWLEDGEMENTS}

The authors thank the Empresa Brasileira de Pesquisa Agropecuária (Embrapa) for the support in executing the study and the Coordenação de Aperfeiçoamento de Pessoal de Nível Superior (Capes) for the master's scholarship. 


\section{SUBMISSION STATUS}

Received: 30 Jan. 2017

Accepted: 31 July 2019

Associate editor: Bruno Araujo Furtado de Mendonça

(D) 0000-0003-0288-0024

\section{CORRESPONDENCE TO Maria Teresa do Rêgo Lopes}

Av. Duque de Caxias, 5.650, Buenos Aires, CEP 64008-780, Teresina, PI, Brasil

E-mail: maria-teresa.lopes@embrapa.br

\section{REFERENCES}

Alcoforado Filho FG, Gonçalves JC. Flora apícola e mel orgânico. In: Vilela SLO, editor. Cadeia produtiva do mel no estado do Piauí. Teresina: Embrapa Meio-Norte; 2000. p. 48-59.

Almeida D, Marchini LC, Sodré GS, D’Ávila M, Arruda CD. Plantas visitadas por abelhas e polinização. Piracicaba: ESALQ; 2003 (Série Produtor Rural, Edição Especial).

Andena SR, Bego LR, Mechi MR. A comunidade de abelhas (Hymenoptera, Apoidea) de uma área de cerrado (Corumbataí, SP) e suas visitas às flores. Revista Brasileira de Zoociências 2005; 7(1): 55-91.

Andrade AD Jr, Bastos EA, Barros AHC, Silva CD, Gomes AAN. Classificação climática do Estado do Piauí. Teresina: Embrapa MeioNorte; 2004.

Angiosperm Phylogeny Group - APG III. An update of the Angiosperm Phylogeny Group classification for the orders and families of flowering plants: APG III. Botanical Journal of the Linnean Society 2009; 161(2): 105-121. 10.1111/j.1095-8339.2009.00996.x

Araújo EL, Silva KA, Ferraz EMN, Sampaio EVSB, Silva SI. Diversidade de herbáceas em microhabitats rochoso, plano e ciliar em uma área de caatinga, Caruaru-PE. Acta Botanica Brasilica 2005; 19(2): 282-297. 10.1590/S0102-33062005000200011

Barth OM. Análise microscópica de algumas amostras de mel. 1. Pólen dominante. Anais da Academia Brasileira de Ciências 1970a; 42(3): 351-366.

Barth OM. Análise microscópica de algumas amostras de mel. 2. Pólen acessório. Anais da Academia Brasileira de Ciências 1970b; 42(3): 571-590.

Barth OM. Análise microscópica de algumas amostras de mel. 3. Pólen isolado. Anais da Academia Brasileira de Ciências 1970c; 42(4): 747-772.

Barth OM. Análise microscópica de algumas amostras de mel. 4. Espectro polínico de algumas amostras de mel do estado do Rio de Janeiro. Revista Brasileira de Biologia 1970d; 30(4): 575-582.

Barth OM. O pólen no mel brasileiro. Rio de Janeiro: Luxor; 1989.

Castro MS. Composição, fenologia e visita às flores pelas espécies de Apidae em um ecossistema de caatinga [dissertação]. São Paulo: Instituto de Biociências, Universidade de São Paulo; 1994.
Chaves EMF, Barros RFM, Araújo FS. Flora apícola do Carrasco no município de Cocal, Piauí, Brasil. Revista Brasileira de Biociências 2007; 5(1): 555-557.

Crane E. O livro do mel. São Paulo: Nobel; 1983.

Instituto Brasileiro de Geografia e Estatística - IBGE. Mel. Produção da Pecuária Municipal 2018 [cited 2020 Feb. 18]; 46: 7. Available from: http://bit.ly/3bHOeo9

Instituto Nacional de Meteorologia - INMET. Banco de Dados Meteorológicos para Ensino e Pesquisa. Dados Históricos [Internet]. [2015?] [cited 2015 Nov. 10]. Available from: http://bit.ly/2u9LKOh

Lopes MTR, Barbosa AL, Vieira Neto JM, Pereira FM, Camargo RCR, Ribeiro VQ et al. Alternativas de sombreamento para apiários. Pesquisa Agropecuária Tropical 2011; 41(3): 299-305. 10.5216/ pat.v41i3.8919

Lopes CGR, Beirão DCC, Pereira LA, Alencar LC. Levantamento da flora apícola em área de cerrado no município de Floriano, estado do Piauí, Brasil. Revista Brasileira de Biociências 2016; 14(2): 102-110.

Lorenzon MC, Matrangolo CA, Schoereder JH. Flora visitada pelas abelhas eussociais (Hymenoptera, Apidae) na Serra da Capivara, em Caatinga do Sul do Piauí. Neotropical Entomology 2003; 32(1): 27-36. 10.1590/S1519-566X2003000100004

Louveaux JA, Maurizio A, Vorwohl G. Methods of melissopalynology. Bee World 1978; 59(4): 139-157. 10.1080/0005772X.1978.11097714

Maia-Silva C, Silva CI, Hrncir M, Queiroz RT, Imperatriz-Fonseca VL. Guia de plantas visitadas por abelhas na caatinga. Fortaleza: Fundação Brasil Cidadão; 2012.

Marengo JA. Vulnerabilidade, impactos e adaptação à mudança do clima no semiárido do Brasil. Parcerias Estratégicas 2008; 27: 149-176.

Malerbo-Souza DT, Silva FAS. Comportamento forrageiro da abelha africanizada Apis mellifera L. no decorrer do ano. Acta Scientiarum. Animal Sciences 2011; 33(2): 183-190. 10.4025/actascianimsci. v33i2.9252

Martins CF, Laurino MC, Koedam D, Fonseca VLI. Espécies arbóreas utilizadas para nidificação por abelhas sem ferrão na caatinga (Seridó, PB; João Câmara, RN). Biota Neotropica 2004; 4(2): 1-8. 10.1590/S1676-06032004000200003

Milet-Pinheiro P, Schlindwein C. Community of bees (Hymenoptera, Apoidea) and plants in an area of Agreste in Pernambuco, Brazil. Revista Brasileira de Entomologia 2008; 52(4): 625-636. 10.1590/ S0085-56262008000400014

Pereira DS, Holanda-Neto JP, Sousa LCFS, Coelho DC, Silveira DC, Hernandez ML. Mitigação do comportamento de abandono de abelhas Apis mellifera L. em apiários no Semiárido Brasileiro. ACTA Apicola Brasilica 2014; 2(2): 1-10. 1018378/aab.v2i2.3507

Pereira FM, Freitas BM, Alves JE, Camargo RCR, Lopes MTR, Vieira Neto JM et al. Flora apícola no Nordeste. Teresina: Embrapa Meio-Norte; 2006.

Pereira FM, Freitas BM, Lopes MTR. Nutrição e alimentação das abelhas. Teresina: Embrapa Meio-Norte; 2011. 
Reis AMS, Araújo EL, Ferraz EMN, Moura AN. Variações interanuais na composição florística e estrutura das populações de uma comunidade herbácea da caatinga, Pernambuco, Brasil. Revista Brasileira de Botânica 2006; 29(3): 497-508. 10.1590/S010084042006000300017

Rodarte ATA, Silva FOD, Viana BF. A flora melitófila de uma área de dunas com vegetação de caatinga, estado da Bahia, Nordeste do Brasil. Acta Botanica Brasilica 2008; 22(2): 301-312. 10.1590/ S0102-33062008000200001

Rolim GS. Flora apicola para Apis mellifera L.(Hymenoptera: Apidae) em municípios sergipanos [dissertação]. São Cristóvão: Universidade Federal de Sergipe; 2015.

Santos E, Matos H, Alvarenga J, Sales MCL. A seca no Nordeste no ano de 2012: relato sobre a estiagem na região e o exemplo de prática de convivência com o semiárido no distrito de Iguaçu/ Canindé-Ce. Revista Geonorte 2012; 2(1): 819-830.

Santos FAR, Oliveira AV, Lima LCL, Barros RFM, Schlindwein CP, Martins CF et al. Apícolas. In: Sampaio EVSB, Pareyn FGC, Figuerôa JM, Santos AG Jr, editors. Espécies da flora nordestina de importância econômica potencial. Recife: APNE; 2005. p. 15-26.

Santos, RF, Kiill LHP, Araújo JLP. Levantamento da flora melífera de interesse apícola no município de Petrolina-PE. Revista Caatinga 2006; 19(3): 221-227.

Santos RG, Domingos HGT, Gramacho KP, Gonçalves LS. Sombreamento de colmeias de abelhas africanizadas no Semiárido brasileiro. Revista Verde de Agroecologia e Desenvolvimento Sustentável 2017; 12(5): 828-836. 10.18378/rvads.v12i5.5407

Scudeller VV, Vieira MF, Carvalho-Okano RM. Distribuição espacial, fenologia da floração e síndrome floral de espécies de Bignonieae (Bignoniaceae). Rodriguésia 2008; 59(2): 297-307. 10.1590/21757860200859203
Silva CADL, Silva DP, Pinto MSC, Silva KB, Targino LC. Levantamento da flora apícola em municípios da microrregião de Catolé do Rocha-PB. Revista Verde de Agroecologia e Desenvolvimento Sustentável 2014a; 9(3): 223-235.

Silva Filho JP, Silva RA, Silva MJS. Potencial apícola para Apis mellifera L. em área de caatinga no período da floração da oiticica (Licania rígida Benth). Revista Verde de Agroecologia e Desenvolvimento Sustentável 2010; 5(1): 120-128. 10.18378/rvads.v5i1.251

Silva GAR, Bastos EM, Sobreira JAR. Levantamento da flora apícola em duas áreas produtoras de mel no estado do Piauí. Enciclopédia Biosfera 2014b; 10(18): 3305-3316.

Silva JS, Sales MF, Carneiro-Torres DS. The genus Croton (Euphorbiaceae) from the microregion of Ipanema Valley, Pernambuco, Brazil. Rodriguésia 2009; 60(4): 879-901. 10.1590/21757860200960409

Silva VPR, Pereira ERR, Azevedo PV, Sousa FAS, Sousa IF. Análise da pluviometria e dias chuvosos na região Nordeste do Brasil. Revista Brasileira de Engenharia Agrícola e Ambiental 2011; 15(2): 131-138. 10.1590/S1415-43662011000200004

Silva RD, Evangelista-Rodrigues A, Aquino IDS, Felix LP, Mata MF, Peronico AS. Caracterização da flora apícola do semiárido da Paraíba. Archivos de Zootecnia 2008; 57(220): 427-438.

Sodré GS, Marchini LC, Moreti ACCC, Carvalho CAL. Tipos polínicos encontrados em amostras de méis de Apis Mellifera em Picos, estado de Piauí. Ciência Rural 2008; 38(3): 839-842. 10.1590/ S0103-84782008000300043

Trovão DB, Souza BC, Carvalho ED, Oliveira PB. Espécies vegetais da Caatinga associadas às comunidades de abelhas (Hymenoptera: Apoidea: Apiformis). Revista Caatinga 2009; 22(3): 136-143.

Vidal MF. Efeitos da seca de 2012 nas exportações nordestinas de mel. Informe Rural Etene [Internet] 2014 [cited 2016 July 16]; 8(3). Available from: https://bit.ly/34oUGMA 